\title{
Age-associated B vitamin deficiency as a determinant of chronic diseases
}

\author{
Patrick Brachet*, Aurélie Chanson, Christian Demigné, Frédérique Batifoulier, Marie-Cécile \\ Alexandre-Gouabau, Viviane Tyssandier and Edmond Rock \\ Unité Maladies Métaboliques et Micronutriments, Institut National de la Recherche Agronomique, Theix, \\ 63122 Saint-Genès Champanelle, France
}

\begin{abstract}
The number of elderly individuals is growing rapidly worldwide and degenerative diseases constitute an increasing problem in terms of both public health and cost. Nutrition plays a role in the ageing process and there has been intensive research during the last decade on B vitaminrelated risk factors in vascular and neurological diseases and cancers. Data from epidemiological studies indicate that subclinical deficiency in most water-soluble B vitamins may occur gradually during ageing, possibly due to environmental, metabolic, genetic, nutritional and pathological determinants, as well as to lifestyle, gender and drug consumption. Older adults have distinct absorption, cell transport and metabolism characteristics that may alter B vitamin bioavailability. Case-control and longitudinal studies have shown that, concurrent with an insufficient status of certain B vitamins, hyperhomocysteinaemia and impaired methylation reactions may be some of the mechanisms involved before a degenerative pathology becomes evident. The question that arises is whether B vitamin inadequacies contribute to the development of degenerative diseases or result from ageing and disease. The present paper aims to give an overview of these issues at the epidemiological, clinical and molecular levels and to discuss possible strategies to prevent $B$ vitamin deficiency during ageing.
\end{abstract}

Ageing: Micronutrients: B vitamin deficiency: Degenerative diseases

Micronutrients such as vitamins and minerals that are essential to biological reactions have been shown to play a role in the ageing process. In developed countries, classical vitamin-deficiency syndromes, such as scurvy, beriberi and pellagra, are now uncommon but specific population subgroups remain at risk for modest vitamin insufficiency. This is notably the case in elderly individuals, who frequently display an inadequate status of vitamin D and water-soluble vitamins including many of the B group. Extensive research in the last decade has suggested that subtle deficiencies in B vitamins are risk factors for degenerative diseases, including vascular diseases, mental health conditions such as dementia and depression, and cancer. The present review aims to report the latest findings on (i) B vitamin bioavailability and status in elderly individuals and (ii) the association of B vitamin insufficiency with chronic diseases. Finally, whether natural foods could deliver enough
B vitamins to achieve the required status and help to prevent or delay the onset of age-associated diseases will be discussed.

\section{B vitamin intake, bioavailability and status in the elderly}

\section{A brief general overview}

Intake of B vitamins is dependent on the food supply. Most $\mathrm{B}$ vitamins are widely distributed in foods, but can be at relatively low concentrations (for example, vitamin $\mathrm{B}_{1}$ ), while others are only provided by certain categories of food (for example, dairy products and meat for vitamin $\mathrm{B}_{12}$ ). Synthetic forms of vitamins are also used for food fortification purposes (for example, folic acid), and for supplements (for example, cobalamin for strict vegetarians).

\footnotetext{
Abbreviations: AD, Alzheimer's disease; CRC, colorectal cancer; CVD, cardiovascular disease; Hcy, homocysteine; MMA, methylmalonic acid; 5-mTHF, methyltetrahydrofolate; 5-MTHFR, methylenetetrahydrofolate reductase; NHANES, National Health and Nutrition Examination Survey; PLP, pyridoxal-5-phosphate; SAM, S-adenosylmethionine; SENECA, Study in Europe on Nutrition and the Elderly, a concerted action; SOD, superoxide dismutase.

* Corresponding author: Dr Patrick Brachet, fax +33 4736247 46, email brachet@clermont.inra.fr
} 
Bioavailability is usually defined as the proportion of micronutrient that is absorbed, then stored by tissues or used metabolically. Clear differences in bioavailability have been observed according to the type of food for a given $\mathrm{B}$ vitamin, on the one hand, and between $\mathrm{B}$ vitamins for a given food, on the other hand (Gregory, 1998; Tucker et al. 2000; Brouwer et al. 2001). Due to functional insufficiencies, the vitamin status of elderly individuals may be subject to higher variability than that of younger adults who are frequently taken as references. Estimation of how much of a B vitamin is required in the elderly must take into account all the potential age-related alterations. In particular, the declining of renal function with advancing age may become a relevant issue when the urinary excretion as well as the blood level of a vitamin, a vitamin metabolite or a biomarker is used as a proxy estimate of its absorption. For instance, serum homocysteine (Hcy) and methylmalonic acid (MMA) levels, which are used for the assay of folate and vitamin $B_{12}$ status, increase in renal insufficiency or hypovolaemia (Savage et al. 1994). Conversely, erythrocyte transketolase activity, which can serve as a biomarker of thiamine (vitamin $\mathrm{B}_{1}$ ) status, seems to decrease steadily over a range from 18 to 90 years (Rooprai et al. 1990).

Bioaccessibility must also be taken into consideration, since the release of $\mathrm{B}$ vitamins from the food matrix can be seriously impaired in age-related physiopathological situations.

Bioavailability assays in human subjects have been reviewed by Gregory \& Quinlivan (2002) in the case of folate, which has been by far the most-studied B vitamin. The issue of biomarkers for $\mathrm{B}$ vitamins involved in one- $\mathrm{C}$ metabolism (vitamin $B_{6}$, folate, vitamins $B_{12}$ and $B_{2}$ ) has recently been addressed by Mason (2003). More general information on bioavailability (absorption, cell transport and metabolism), food distribution, stability (under physicochemical conditions or during food processing, storage and cooking), chemical structures and functions of B vitamins can be obtained from the Institute of Medicine, National Academy of Sciences (1998) and the Handbook of Vitamins (Rucker, 2001). The present review will consider mainly vitamins $\mathrm{B}_{1}$ (thiamin), $\mathrm{B}_{2}$ (riboflavin), $\mathrm{B}_{6}$ (pyridoxine), folate and vitamin $\mathrm{B}_{12}$ (cobalamin), since the other $B$ vitamins (niacin, pantothenic acid and biotin) have been little studied in relation to ageing. As shown in Fig. 1, interactions may exist intracellularly between the metabolism of the different $\mathrm{B}$ vitamins.

\section{$B$ vitamin intake and status in the elderly population}

In a variety of countries, health and nutrition examination surveys have been used to estimate the dietary and total intake, as well as the status, of B vitamins in the elderly population. These include the third National Health and Nutrition Examination Survey 1988-1994 (NHANES III) and the elderly Framingham Heart Study cohort in the USA, and the National Diet and Nutrition Survey in the UK. Health and nutrition examination surveys in Europe also include the EURONUT Study in Europe on Nutrition and the Elderly, a concerted action (SENECA) in eleven European countries, the Dutch Nutrition Surveillance System in the Netherlands, the French Burgundy 'Etude du Statut VITAminique des Français' (ESVITAF) and
'SUpplementation en VItamines et Minéraux AntioXydants' (SU.VI.MAX) studies. However, a global assessment of the prevalence of B vitamin deficiency is rendered difficult by several factors. These include: (i) the unequal reliability of measurements of dietary intakes; (ii) discrepancies between status data based on different biomarkers and cut-off values; (iii) inter- and intra-method variations for vitamin assays; (iv) heterogeneity of the populations studied due to different regional origins or, especially as regards the elderly, to more or less extensive exclusions of individuals with certain diseases and treatments.

Other determinants of B vitamin deficiency in the elderly include:

The environment (institutionalisation (Essama-Tjani et al. 2000), hospitalisation, level of skilled nursing care, loneliness, income);

Gender (there may be a higher prevalence of B vitamin deficiency in elderly men than in women);

Lifestyle (smoking, sedentariness, excessive chronic consumption of alcohol), especially for vitamins $\mathrm{B}_{1}, \mathrm{~B}_{6}$ and folate (van den Berg et al. 2002);

Vegetarianism, especially for vitamin $\mathrm{B}_{12}$;

Genetic variations; for example, polymorphisms in the gene coding for methylenetetrahydrofolate reductase (MTHFR) (Meleady et al. 2003).

For instance, a reduced energy intake and vitamin bioavailability due to increased morbidity (chronic diseases and/or disability) and possibly concurrent drug consumption increase the risk for impaired B vitamin status in fragile elderly individuals (Desouza et al. 2002). Thus, controversy exists as to whether low plasma concentrations of $B$ vitamins observed in the elderly strictly reflect changes with advancing age. Theoretically, the contribution of the ageing process per se to B vitamin deficiency should only be assessed in healthy elderly adults.

The intake of vitamins $\mathrm{B}_{1}, \mathrm{~B}_{2}, \mathrm{~B}_{6}$ or folate below the recommended levels has been repeatedly reported in various groups of elderly individuals (Amorim Cruz et al. 1996; van der Wielen et al. 1996; Marshall et al. 2001). Regarding vitamin $\mathrm{B}_{12}$, very few, if any, of the elderly individuals studied, except those who were food-insecure, displayed insufficient intakes (Howard et al. 1998).

In a cross-sectional and 3-year longitudinal survey in New Zealand, the erythrocyte thiamin pyrophosphate concentration in elderly subjects, which was initially $32 \%$ lower than in younger subjects, was further decreased by $20 \%$ at the end of the study (Wilkinson et al. 2000). Such changes appeared to be related more to ageing than to comorbidities. Low thiamin status was also reported concurrent with apparently normal intake in Canadian free-living elderly subjects (Nichols \& Basu, 1994). Ageing has been shown to be associated with a decreased passive diffusion permeability and a decreased affinity of the saturable transporter for thiamin despite an increased number of carriers (Gastaldi et al. 1992). Whether this may be related to the upregulation of intestinal transporters of vitamin $B_{1}$ by vitamin deficiency (also reported for vitamin $B_{2}$ and folate) remains to be elucidated.

The prevalence of poor riboflavin status in elderly individuals is between 16 and $45 \%$ in most of the communities surveyed (Boisvert et al. 1993; Lopez-Sobaler et al. 2002). 


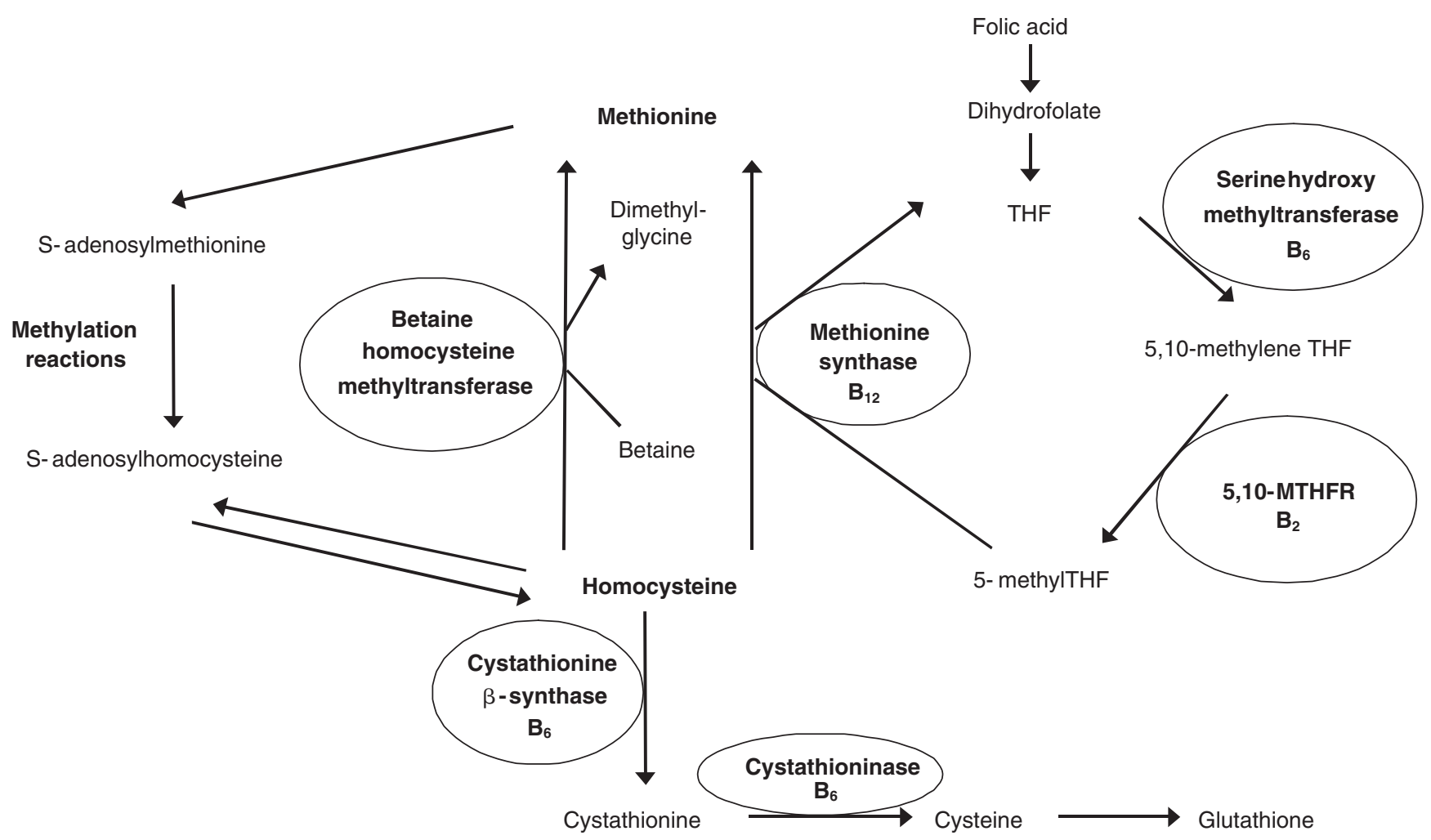

Fig. 1. Metabolic interactions between folate and other B vitamins. Additionally, methionine synthase reductase which catalyses the NAPDHdependent reductive methylation of methionine synthase is a flavoprotein. It should also be noted that 5,10-methylenetetrahydrofolate is a substrate for purine synthesis via 10-formyl tetrahydrofolate and for thymidylate synthesis with the release of dihydrofolate. THF, tetrahydrofolate; MTHFR, methylenetetrahydrofolate reductase.

Even more (77\% men, $79 \%$ women) appeared to be at risk of riboflavin deficiency among free-living British elderly aged 68-90 years (Bailey et al. 1997). Moreover, Madigan et al. (1998) observed vitamin $\mathrm{B}_{2}$ deficiency in elderly individuals with apparently adequate dietary intake. Such a paradox may indicate the possible malabsorption of vitamin $\mathrm{B}_{2}$ in this population.

Using plasma pyridoxal-5-phosphate (PLP) as a biochemical marker, a high prevalence of vitamin $\mathrm{B}_{6}$ deficiency was also observed in the studies of Bailey et al. (1997) and Madigan et al. (1998). An insufficient status of vitamin $B_{6}$ in 13 to $45 \%$ of aged individuals was also suggested by many other studies using the same indicators or others (Selhub et al. 1993; Haller, 1999). Moreover, vita$\min \mathrm{B}_{6}$ deficiency was found to increase with increasing age among the elderly population (Herrmann et al. 1999; Ravaglia et al. 2000). The ageing-dependent deficiency of vitamin $\mathrm{B}_{6}$ could be due to changes at post-intestinal, cellular transport and/or metabolism levels rather than due to changes at the level of intestinal absorption (van den Berg, 1999). Alteration in the slowly exchanging vitamin $B_{6}$ pools, i.e. increased hydrolysis of PLP to pyridoxal before pyridoxal oxidation, has been reported in older rats. Higher vitamin $B_{6}$ catabolism in the elderly may lead to increased vitamin needs and reduced PLP-protein binding capacities. Moreover, plasma PLP concentrations in elderly individuals seem to be related to both the decrease in lean body mass (mainly muscle protein) that occurs during ageing and the level of protein intake.

Assessments of folate status in the elderly have provided variable data. Various groups of elderly individuals such as the US Framingham original cohort (Selhub et al. 1993), free-living elderly Canadian residents (Quinn \& Basu, 1996), Hispanics in New Mexico (Lindeman et al. 2000) and apparently healthy Chilean subjects (Olivares et al. 2000) were found to be folate deficient or at risk of deficiency. However, this was observed in less than $10 \%$ of German and Northern Italian elderly (Herrmann et al. 1999; Ravaglia et al. 2000) while no differences occurred for plasma folate, as well as vitamins $\mathrm{B}_{6}$ and $\mathrm{B}_{12}$, concentrations between Singapore Chinese groups aged 45-74 years (Saw et al. 2001). Human studies have suggested that ageing per se might have little effect on the activity of intestinal $\gamma$-glutamylhydrolase (conjugase), the enzyme responsible for the hydrolysis of dietary folate polyglutamates to folate monoglutamates, or on the absorption of the latter (Bailey et al. 1984). However, because the optimum $\mathrm{pH}$ for those activities is $6 \cdot 5-7 \cdot 0$ and $6 \cdot 0-6 \cdot 3$, respectively, digestive pathologies in the elderly (especially those eliciting $\mathrm{pH}$ modifications in the stomach and the upper intestine) could alter folate bioavailability (Kesavan \& Noronha, 1983). Hypochlorhydria, that affects 10 to $40 \%$ of the elderly, can decrease folate absorption, but normality can be recovered following acid administration (Russell, 2000). 
Moreover, it is not currently known whether enterohepatic cycling, which represents an important pathway for the redistribution of folate to peripheral tissues (more than $80 \mu \mathrm{g} / \mathrm{d}$ ), may be altered by ageing.

Hypochlorhydria impairs the dissociation of vitamin $B_{12}$ from food complexes and, subsequently, its release into the lumen of the small intestine. Type A or B atrophic gastritis is associated with pernicious anaemia or Helicobacter pylori infection, respectively. Pernicious anaemia, as well as gastrectomy, causes vitamin $\mathrm{B}_{12}$ malabsorption. Although they may also be a source of B vitamins (Camilo et al. 1996), overgrowing gastrointestinal bacteria could capture cobalamin freed from food complexes (van Asselt et al. 1998). All of these conditions may explain why vitamin $B_{12}$ status is altered in a substantial fraction of elderly individuals although current recommendations for this vitamin are met (Baik \& Russell, 1999). NHANES III data reported an age-dependent prevalence of low serum vitamin $\mathrm{B}_{12}$ concentration (i.e. $9 \%$ between 50 and 59 years; $13 \%$ for $\geqslant 70$ years), in agreement with other studies (Herrmann et al. 1999; Ravaglia et al. 2000). In the SENECA study, based on plasma cobalamin and MMA levels, only $25.7 \%$ of apparently healthy, free-living Dutch elderly (74-80 years) were not cobalamin deficient (van Asselt et al. 1998). Increased serum MMA (and tHcy) levels were also reported in $49 \%$ of normal Swedish individuals aged $\geqslant 70$ years (Björkegren \& Svärdsudd, 2001). A recent population-based study found that about 10 and $20 \%$ of individuals living in Oxford (UK) and aged 65-74 and $\geqslant 75$ years, respectively, were at high risk of vitamin $\mathrm{B}_{12}$ deficiency; about $10 \%$ of these vitamin $\mathrm{B}_{12}$-deficient individuals also showed folate deficiency (Clarke et al. 2003). Observations indicate that the serum concentration of vita$\min B_{12}$ is maintained at the expense of tissue stores. Thus, while a serum concentration below the classical cut-off value defining vitamin $\mathrm{B}_{12}$ deficiency (120-180 pmol/l) indicates long-term depletion, a level above this value does not necessarily mean adequate vitamin $\mathrm{B}_{12}$ status. Altered binding to plasma transcobalamin II proteins or an altered cellular metabolism of cobalamin may also occur during ageing (van Asselt et al. 1998).

\section{$B$ vitamin deficiency and degenerative pathologies}

An insufficient status of folate, cobalamin, vitamin $B_{6}$ and, to a lesser extent, vitamins $B_{2}$ and $B_{1}$, is currently recognised as a risk factor for chronic diseases (cardiovascular diseases (CVD), cognitive and neuropsychiatric dysfunction and certain cancers) and can also exacerbate existing pathologies in the elderly.

\section{Hyperhomocysteinaemia}

Hcy re-methylation to methionine, and catabolism via the trans-sulfuration pathway, require folate, cobalamin, vita$\min \mathrm{B}_{6}$ and riboflavin, which have proved to be more or less effective determinants of plasma fasting Hcy concentrations (tHcy normal range about $10 \mu \mathrm{mol} / \mathrm{l}$ ). Hyperhomocysteinaemia is usually defined as a tHcy $>15 \mu \mathrm{mol} / 1$, although differences exist between the reported reference ranges. Its prevalence is about $5 \%$ in the normal population, but it seems to increase with age (Nygard et al. 1995). Prevalence of mild hyperhomocysteinaemia was $29.3 \%$ in individuals aged 67 to 96 years from the original Framingham Heart Study cohort (Selhub et al. 1993) and $61 \%$ in elderly hospitalised patients (Ventura et al. 2001). However, $72 \%$ of thcy in the latter group could be explained by variables other than age. Data from the NHANES III reported homocysteinaemia higher in males than in females at younger ages, but converging at older ages in both genders (Jacques et al. 1999a). Low serum folate levels have a central role in the pathogenesis of hyperhomocysteinaemia. For instance, in the elderly participants from the Framingham Heart Study cohort, mean tHcy was significantly higher in the lowest two deciles than in the highest decile of plasma folate concentrations. Serum vitamin $\mathrm{B}_{6}$ and/or $\mathrm{B}_{12}$ levels are also inversely associated with Hcy levels, but the relationship appears to be weaker than for folate. However, no correlation was found between tHcy and vitamin $\mathrm{B}_{12}$ status in some studies (Hermann et al. 1999). The intake of folate and vitamin $\mathrm{B}_{6}$, but not vitamin $B_{12}$, is generally inversely associated with tHcy (Selhub et al. 1993).

The meta-analysis of randomised trials estimates that folate supplementation $(0 \cdot 5-5 \mathrm{mg} / \mathrm{d})$ can reduce tHcy by $25 \%$ and that the addition of vitamin $\mathrm{B}_{12}(0.5 \mathrm{mg} / \mathrm{d})$ can reduce it by a further $7 \%$, with no further change following the addition of vitamin $\mathrm{B}_{6}(16.5 \mathrm{mg} / \mathrm{d})$ (Homocysteine Lowering Trialists' Collaboration, 1998). Nevertheless, such predictions may not be valid for the elderly, where baseline thcy values often exceed the $10-15 \mu \mathrm{mol} / \mathrm{l}$ range. For instance, in a randomised, double-blind, placebo-controlled trial in healthy individuals aged 63-80 years, not deficient in vitamin $\mathrm{B}_{12}$, and who were made replete with folate and riboflavin, hyperhomocysteinaemia could be counteracted by a moderate vitamin $\mathrm{B}_{6}$ supplementation ( $1.6 \mathrm{mg} / \mathrm{d}$ for 12 weeks; McKinley et al. 2001). Regarding the $677 \mathrm{C} \rightarrow \mathrm{T}$ (Ala222Val) variant of MTHFR, higher plasma folate and lower tHcy can occur in wild-type CC subjects when compared with TT and, to a lesser extent, CT subjects (de Bree et al. 2003). TT homozygotes require more dietary folate to achieve a plasma folate concentration identical to that in CC homozygotes. In a cross-sectional study of healthy subjects aged 19-63 years, mild hyperhomocysteinaemia typically associated with TT homozygosity occurred only with poor riboflavin status (McNulty et al. 2002). Folate and riboflavin could interact to lower tHcy by maximising the catalytic activity of MTHFR. However, it was recently suggested that this effect may be unrelated to MTHFR genotype (Moat et al. 2003). Moreover, while riboflavin intake could influence tHcy among non-supplement users in a population-based cohort (Jacques et al. 2001), supplemental riboflavin was not an effective tHcylowering agent in healthy elderly individuals with sub-optimal vitamin $B_{2}$ status (McKinley et al. 2002). The impact of other gene polymorphisms on tHcy has been reviewed by Lievers et al. (2003).

\section{Cardiovascular diseases}

Numerous cross-sectional and case-control studies have provided evidence for the probable existence of an associa- 
tion between mildly elevated tHcy and CVD. The prevalence of hyperhomocysteinaemia is 13-47 \% among patients with atherosclerotic disease (Malinow et al. 1998). A meta-analysis involving 5230 individuals from seventeen studies relating tHcy to coronary artery disease risk and eleven studies of folate effects on tHcy suggested that a $5 \mu \mathrm{mol} / \mathrm{l}$ increment in homocysteinaemia is associated with a $60 \%$ increased risk in men (Boushey et al. 1995). More recently, it was predicted that a $3 \mu \mathrm{mol} / 1$ decrease in homocysteinaemia following an increased intake of folate would reduce the risk of IHD, deep-vein thrombosis and stroke by 16, 25 and $24 \%$, respectively (Wald et al. 2002). Data from prospective cohort studies are less strong than those from case-control studies in support of the relationship between elevated tHcy and the risk of CVD, especially in adults healthy at the study baseline. For instance, in the longitudinal Physician's Health Study (40-84-year-old men followed for 7.5 years), the individuals with the lowest $20 \%$ of plasma folate or vitamin $\mathrm{B}_{6}$ concentrations had a relative risk of $1.4(95 \%$ CI $0 \cdot 9,2 \cdot 3)$ or $1.5(95 \%$ CI $1 \cdot 0,2 \cdot 2)$, respectively, compared with those in the top $80 \%$ (ChasanTaber et al. 1996). Although not statistically significant, the results suggest that a low dietary intake and low plasma concentrations of folate and/or vitamin $\mathrm{B}_{6}$, on the one hand, and high tHcy, on the other hand, contribute to the risk of myocardial infarction. Other reports have reached a similar conclusion regarding atherosclerosis (Robinson et al. 1998). Some studies suggested that vitamin $B_{6}$ may offer independent protection against cardiovascular mortality (Folsom et al. 1998), but others did not (Medrano et al. 2000). These two reports also yielded contradictory results concerning vitamin $\mathrm{B}_{12}$. The reason for such a discrepancy between studies is not known, as study populations, age of subjects or follow-up time do not appear to explain the different findings. Data from NHANES III indicate that the association between serum folate and the risk of CHD differed significantly by age groups (Giles et al. 1998). They notably reported an inverse relationship only in adults aged 35-55 years, suggesting that the greatest potential for prevention might be achieved by increasing folate levels in young adults. A meta-analysis of data from forty case-control studies has indicated that individuals with the MTHFR 677TT genotype have a $16 \%$ (odds ratio $1 \cdot 05-1 \cdot 28$ ) higher risk of CHD compared with CC individuals. However, the result was significant in European populations unlike North American populations (Klerk et al. 2002). In the European Concerted Action Project, the TT genotype was found to confer a modest increase in vascular disease risk (Meleady et al. 2003). In the latter two studies, the risk increase was mainly mediated by low folate status.

\section{Cognitive and neuropsychiatric dysfunction}

Low dietary intakes or mild deficits of B vitamins have been associated with subtle or important neuropsychological impairment in the elderly.

Studies have suggested that low free thiamin levels in cerebrospinal fluid could be related to the risk for Parkinson's disease (Jimenez-Jimenez et al. 1999) and have found a relationship between vitamin $\mathrm{B}_{1}$ levels in plasma or autopsied cerebral cortex and cognitive impairment in patients with dementia of the Alzheimer's disease (AD) type (Gold et al. 1995). However, data on the effect of long-term administration of thiamin on the progression of $\mathrm{AD}$ are conflicting and no association seems to exist between cerebrospinal fluid thiamin levels and the risk for, or the progression of, this disease.

More frequently, low folate, vitamin $\mathrm{B}_{6}$ and/or $\mathrm{B}_{12}$ status-dependent hyperhomocysteinaemia in adults may be a risk factor for poor cognition, depression, dementia, $\mathrm{AD}$ and Parkinson's disease (Gonzalez-Gross et al. 2001). A positive correlation between the levels and mental health (assessed by the Mini-Mental State Examination) has been observed among the 5-year-follow-up of elderly participants in the European, multicentre, SENECA study. However, no such association was detectable in the Finale study, probably because the population size was almost one half that in the follow-up study, and represented the healthiest segment of the cohort (Eussen et al. 2002). The Canadian Study of Health and Ageing reported low serum folate levels independently associated with a higher risk of adverse cerebrovascular events among older, cognitively fragile individuals (Maxwell et al. 2002). Moreover, elderly individuals deficient in vitamin $\mathrm{B}_{12}$ can develop neuropsychiatric abnormalities, such as depression, that are not seen in folate deficiency, suggesting effects specific to cobalamin metabolic, environmental or genetic factors (Tiemeier $\mathrm{et} \mathrm{al}$. 2002). Cognitive recovery after supplementation with pharmacological doses of vitamin $\mathrm{B}_{12}$ has been demonstrated in patients with cobalamin deficiency (van Asselt et al. 2001). However, it depends on the duration of symptoms and the magnitude of neurological complications.

Community-based studies have shown that elevated tHcy may be an independent risk factor for cerebral infarction (Shimizu et al. 2002), as well as decreased cognitive performance in normally ageing individuals (Teunissen $e t$ al. 2003). Whether this condition precedes the onset of dementia, or results from dementia-related nutritional and vitamin deficiencies, is currently unknown. The first assumption is supported by the observation of a strong relationship between newly diagnosed dementia and AD with high tHcy measured 8 years before baseline in cognitively intact adults (Seshadri et al. 2002). Nevertheless, there are conflicting results as regards the existence of such an association between baseline hyperhomocysteinaemia and cognitive decline, as measured by changes in the MiniMental State Examination score (Kalmijn et al. 1999; Miller et al. 2003; Ravaglia et al. 2003). In particular, this association was not observed in centenarians, perhaps due to biological characteristics that are different from those of younger elderly individuals. A relationship between stroke and $\mathrm{AD}$ seems to exist and it has been suggested that elevated tHcy in patients with $\mathrm{AD}$ is rather related to vascular disease than to AD pathology (Miller et al. 2002). In the present study, low vitamin $\mathrm{B}_{6}$ status was prevalent in $\mathrm{AD}$ patients, suggesting that it might also influence the pathogenesis or progression of the disease.

\section{Cancer}

There have been many investigations on the relationship between inadequate intake and/or status of B vitamins and 
cancers, especially those of the gastrointestinal tract. Regarding vitamins $\mathrm{B}_{1}$ and $\mathrm{B}_{2}$, the data are often contradictory and far from conclusive. Studies have suggested that, under certain circumstances, such as high fat intake or smoking, methyl-donor (for example, folate) and/or PLP deficiency may influence cell differentiation in the pancreas and contribute to the pathogenesis of pancreatitis and carcinogenesis (Stolzenberg-Solomon et al. 1999). Low dietary folate and/or vitamin $\mathrm{B}_{6}$ have frequently been related to an increased occurrence of colorectal adenoma. Among the various components of vegetables and fruits, only soluble fibre and vegetables high in folate were found to be independently related to a lower risk of colorectal adenoma (Platz et al. 1997). A lower level of erythrocyte folate was additionally observed in colonic adenoma cases as compared with controls, however, with possible gender specificity (Bird et al. 1995). Supplementation with $2 \mathrm{mg}$ folic acid/d for 3 months caused decreased colonic mucosal cell proliferation in patients with recurrent adenomatous polyps (Khosraviani et al. 2002). Moreover, the risk of adenoma formation, growth or recurrence could increase when high alcohol and low folate intakes are combined.

An inverse association of folate intake or blood folate with colorectal cancer (CRC) risk has also been reported (Giovannucci, 2002). A pooled analysis of nine prospective cohort studies suggested that a daily intake of $400-500 \mu \mathrm{g}$ folate should be sufficient for minimising the risk of CRC. No clear differences in CRC risk apparently exist regarding the type of folate vitamers ingested (Konings et al. 2002). The NHANES I epidemiological follow-up study reported a significant relationship between folate intake and reduced colon cancer risk only among men and non-drinkers $(\mathrm{Su} \&$ Arab, 2001). It also supported a synergistic interaction between folate and methionine intakes. Methionine may be beneficial through DNA methylation or the sparing of folate required for DNA synthesis and repair. Low intracellular levels of methionine cause an increased S-adenosylhomocysteine:S-adenosylmethionine (SAM) ratio, thus stimulating MTHFR and allowing 5-methyltetrahydrofolate (5-mTHF) to provide Hcy with a methyl group to form methionine (Finkelstein, 1998). However, if the 5-mTHF level is insufficient, cell methylation reactions can be affected. Only a few studies have reported directly on methionine intake and the existence of an inverse association with CRC is not clearly demonstrated. Individuals with 'methyl-poor' diets (for example, high in alcohol and low in folate and methionine) are at markedly higher risk of colorectal adenoma or CRC compared with those with 'methyl-rich' diets (Fuchs et al. 2002).

The TT genotype for the C677T variant of MTHFR may confer a relatively lower risk of CRC or adenoma than the $\mathrm{CC}$ or CT genotypes, provided that it is concurrent with a 'methyl-rich' diet (Ma et al. 1997) or high vitamin $\mathrm{B}_{6}$ and folate intake (Le Marchand et al. 2002). Under conditions of low folate intake, the TT variant has been linked to reduced levels of plasma folate, aberrant DNA methylation in leucocytes and an increased risk of CRC, especially in older populations, possibly due to age-related disturbances in folate metabolism (Shannon et al. 2002). The association of other polymorphisms in the MTHFR, methionine syn- thase or cystathionine $\beta$-synthase gene with $\mathrm{CRC}$ has been suggested, but remains to be established.

Prospective case-cohort studies suggest an inverse relationship between dietary folate and lung cancer (Voorrips et al. 2000). However, no association was found between folate intake, or serum and erythrocyte levels and nonsmall-cell lung cancer (Jatoi et al. 2001). A significant relationship between lung cancer incidence and serum vitamin $\mathrm{B}_{6}, \mathrm{~B}_{12}$ or tHcy, but not folate, was reported by Hartman et al. (2001). The risk of breast cancer was the highest with low folate, and possibly vitamin $\mathrm{B}_{6}$, plasma levels, particularly among women with high alcohol consumption (Zhang et al. 2003). A large, multi-ethnic community-based, case-control US study of invasive cervical cancer, at least 6 months after completion of cancer treatment, reported a substantially and significantly higher risk for women in the upper three quartiles of homocysteinaemia, but no association was found with circulating folate (Ziegler et al. 2002). Whether elevated tHcy is a risk factor for carcinogenesis or a tumour marker in cancer patients remains to be demonstrated. The C677T variant in the MTHFR gene may increase the risk for several cancers, except for lung cancer, in elderly men, especially those with a low folate and a high alcohol intake (Heijmans et al. 2003).

\section{Mechanisms of the effects of age-associated B vitamin deficiency}

\section{Alteration of methylation reactions}

Chronic nutritional deficiencies in B vitamins, choline (betaine) and/or methionine can perturb the complex regulatory network maintaining normal one-C metabolism and Hcy homeostasis (see Fig. 1). 5-mTHF synthesis occurs from one-C units provided by serine or from methyl groups of choline while de novo synthesis of choline via SAM uses methyl groups from methionine. Altering the metabolism of one of these pathways results in compensatory changes in the others. For instance, in addition to the previously mentioned interaction between methionine and 5-mTHF, folate deprivation may cause a higher use of methyl groups from choline and an increased dietary requirement for choline (Niculescu \& Zeisel, 2002).

Folate deficiency can affect the configuration and structural stability of DNA through two potential pathways: the transfer of methyl groups from 5,10-methyleneTHF to uracil and the conversion of the latter to thymine for DNA synthesis and repair. Additionally, it may cause misincorporation of uracil into DNA, leading to double strand breaks and chromosomal damage. Folate can also affect gene promoter activity by regulating cellular levels of SAM, the substrate of DNA methyltransferases that contribute to the high conservation of the methylation patterns of genomic cytosine residues after cell replication (Duthie et al. 2002). Methylation of cytosine residues, often within the promoter regions of genes, is essential for the control of gene transcription and genetic stability. Increased serum and tissue levels of S-adenosylhomocysteine, concomitant with chronic hyperhomocysteinaemia, have been shown to inhibit DNA methyltransferases and thus to contribute to DNA hypomethylation (James et al. 2002). In contrast to 
DNA hypermethylation, DNA hypomethylation may cause the overexepression of genes (for example, proto-oncogenes), and lead to cancer in mitotic cells while in postmitotic cells (for example, neurones), it may promote cell death (Mattson et al. 2002). Genetic polymorphism can act synergistically with nutritional deficiencies to perturb methylation reactions. For instance, TT homozygotes for the C677T variant of MTHFR have been shown to display genomic hypomethylation in peripheral leucocytes (Stern et al. 2000). Additionally, imbalance between biological methylation and nucleotide synthesis at the MTHFR reaction level may be important in folate-related carcinogenesis (Choi \& Mason, 2002).

Ageing, as well as most chronic diseases, is partly caused by damage to both nuclear and mitochondrial DNA. Ageing, marginal deficiencies in folate or vitamin $\mathrm{B}_{12}$ and elevated tHcy are accompanied by spontaneous chromosome damage, as measured by micronucleus formation in blood and epithelial cells. Normalisation of DNA methylation by folate repletion seems to be delayed in older women with moderate folate depletion (Rampersaud et al. 2000). Double-blind placebo-controlled intervention studies conducted over 4 months indicated that chromosomal damage and DNA hypomethylation are minimised when erythrocyte folate concentration is higher than $700 \mathrm{nmol} / \mathrm{l}$, while micronucleus formation is the lowest when the plasma concentration of vitamin $B_{12}$ is above $300 \mathrm{pmol} / \mathrm{l}$ and plasma tHcy is below 7.5 $\mu \mathrm{mol} / \mathrm{l}$ (Fenech, 2002). Moreover, folate insufficiency and ageing in rats have been shown to be concurrent with non-enzymic modification of aspartyl and asparaginyl residues in proteins and peptides (Ghandour et al. 2002). This may be related to the decreased activity of protein-L-isoaspartyl methyltransferase, since this enzyme allows re-isomerisation, and restoration of the original $\alpha-$ peptide linkage by catalysing the transfer of the methyl group of SAM to altered L-isoaspartyl sites of proteins.

\section{Pro-oxidative effects}

$B$ vitamins could provide protection against oxidative stress either by decreasing pro-oxidant Hcy in plasma and/or more directly by scavenging reactive oxygen species. Oxygen-dependent auto-oxidation of Hcy occurs when added to serum or in the presence of transition metals $\left(\mathrm{Fe}^{2+}\right.$, $\mathrm{Cu}^{2+}$ ), leading to homocysteine formation and the generation of superoxide anions, $\mathrm{O}_{2}^{--}$and hydroxyl radicals, $\cdot \mathrm{OH}$. Hcy bound to LDL may facilitate their oxidation through this mechanism (Olszewski \& McCully, 1993). It also may promote atherogenesis through the effects of oxidised LDL on monocyte recruitment and macrophage differentiation, as well as on the formation of lipid-laden foam cells (Duell \& Malinow, 1997). Additionally, Hcy auto-oxidation may contribute to endothelial dysfunction: $\mathrm{O}_{2}^{-\cdot}$ production can interact with the endothelium-derived relaxing factor NO to form peroxynitrite, which in turn leads to the inactivation of the biological functions of NO (Zhang et al. 2000). High circulating tHcy lowered the endothelium-dependent vasomotor response in healthy older individuals (Hirsch et al. $2002 b$ ) and this effect could be reversed by intracellular $\mathrm{O}_{2}^{-*}$ scavengers (Lang et al. 2000). Also, the methionineinduced impairment of resistance vessel dilatation to acetylcholine or bradykinin in human subjects was prevented by the oral administration of antioxidant vitamins (Raghuveer et al. 2001). However, there was also evidence for oxidative stress-independent endothelial dysfunction after oral methionine loading in human subjects (Nightingale et al. 2001).

As regards total antioxidant capacities or oxidative damage, different magnitudes of tHcy increase may account for the discrepant observations in vivo. Impaired endotheliumdependent relaxation of coronary resistance vessels, as well as increased carotid arterial permeability and initiation of arterial stiffening, in folate-depleted, hyperhomocysteinaemic rats was associated with increased oxidative $(\mathrm{Cu}-\mathrm{Zn}+\mathrm{Mn}$ superoxide dismutase (SOD) activity) and glycoxidative (pentosidine) stress (Symons et al. 2002). Elevated tHcy in patients seemed to evoke an adaptive increase in the activity of the antioxidant enzymes glutathione peroxidase and, to a lesser extent, SOD in the circulation (Moat et al. 2000). However, a 4-week folate-depletion period gave rise to decreased glutathione peroxidase and SOD activities and increased lipid peroxidation in rat liver (Huang et al. 2001).

Long-term (1-year) supplementation with pharmacological doses of folic acid improved arterial endothelial function in hyperhomocysteinaemic healthy volunteers (Woo et al. 2002). In patients suffering from CVD, this treatment decreased tHcy, fibrinogen, malondialdehyde and von Willebrandt factor levels, and increased plasminogen, antithrombin III, GSH, glutathione peroxidase and SOD levels concurrently. Nevertheless, there is currently no general consensus regarding the ability of Hcy-lowering treatments to increase plasma antioxidant activity or to improve endothelial function. In particular, it has been suggested that the impaired bioavailability of NO in hyperhomocysteinaemia is secondary to the accumulation of the endogenous NO synthase inhibitor asymmetric dimethylarginine (Sydow et al. 2003).

Moreover, the administration of 5-mTHF $(5 \mathrm{mg} / \mathrm{d}$ for 6 weeks) to patients with coronary artery disease improved flow-mediated dilatation without affecting their homocysteinaemia, thus suggesting the involvement of a Hcy-independent mechanism (Doshi et al. 2002). A similar mechanism could be responsible for the restoration of forearm blood flow by a high concentration of 5-mTHF after the stimulation of endothelium-dependent vasodilatation in patients with familial hypercholesterolaemia (Verhaar et al. 1998). Based on the hypothesis of impaired NO availability, folate might increase the NO level by reducing the $\mathrm{O}_{2}^{-\cdot}$ level in a dose-dependent manner. Folate was actually found to react with free radicals at an almost diffusion-controlled rate, thus forming a delocalised molecular radical, and to inhibit microsomal lipid peroxidation in a concentration-dependent way (Joshi et al. 2001). Studies have also suggested antioxidant properties for vitamins $\mathrm{B}_{2}$ and $\mathrm{B}_{6}$ in rats submitted to oxidant-mediated inflammatory lung injury (Seekamp et al. 1999) and exercise-induced oxidative stress (Benderitter et al. 1996), respectively.

Many factors associated with brain ageing (i.e. cerebral microangiopathy, endothelial dysfunction, impaired NO activity, oxidant damage to neurones, altered methylation 
reactions) are related to hyperhomocysteinaemia and altered one-C metabolism due to folate deficiency. The ability of the latter condition to exacerbate dopamine depletion, neuronal degeneration and motor dysfunction induced by environmental toxins suggests a mechanism whereby dietary folate may influence the risk for Parkinson's disease (Duan et al. 2002). Additionally, a relationship between increased Hcy concentrations and (E)-4-hydroxy-2-nonenal, a neurotoxic product of lipid peroxidation in the ventricular fluid and brain, has been observed in patients with AD (Selley et al. 2002).

\section{Prevention of $\mathbf{B}$ vitamin deficiency during ageing}

Cereals, vegetables, legumes and fruits on the one hand, and meats, fish and dairy products, on the other hand, contribute mainly to $\mathrm{B}$ vitamin intake in the populations of developed countries. Offal (mainly liver) contains potentially important sources of B vitamins, but it is a lower contributor to total intake because it is consumed in relatively small amounts. Fruit and vegetables constitute essential sources in a multitude of vitamins (apart from vitamin $\mathrm{B}_{12}$ ), and other biologically active micronutrients: natural antioxidants, carotenoids, flavonoids, minerals, etc. Aiming to prevent chronic diseases (Potter, 2002), experts of nutrition-health programmes of Western countries recommend the consumption of at least five foods of fruit or vegetable origin daily. However, the percentage of individuals following this recommendation may be limited, suggesting an important risk of micronutrient deficiency in the population. For instance, while the recommended dietary allowance is $400 \mu \mathrm{g}$ dietary folate equivalents/d, NHANES III reported a median intake of folate from food amounting to about $250 \mu \mathrm{g} / \mathrm{d}$ in the US adult population from 1988 to 1994 (Institute of Medicine, National Academy of Sciences, 1998). The increased consumption of vegetables and citrus fruit increases plasma folate levels and diminishes tHcy in healthy volunteers (Brouwer et al. 1999; Broekmans et al. 2000).

To reduce the risk of neural-tube defects in the newborn by increasing folate intake in women of childbearing age, manufacturers of cereal-grain foods have been required to add folic acid in several countries; for example, at a concentration of $140 \mu \mathrm{g} / 100 \mathrm{~g}$ product in the USA. Additionally, a significant fraction of the general population (for example, about $40 \%$ of North Americans) is already consuming nutritional supplements. These are mainly as vitamin and mineral supplements (Ervin et al. 1999) that usually provide around $400 \mu \mathrm{g}$ folate, $3 \mathrm{mg}$ vitamin $\mathrm{B}_{6}$ and $9 \mu \mathrm{g}$ vitamin $\mathrm{B}_{12} / \mathrm{d}$, i.e. about 127,183 and $375 \%$ of the recommended dietary allowances, respectively (McKay et al. 2000). The total daily intake of folate increased by about $323 \mu \mathrm{g}$ of food folate equivalents in the American population exposed to folate fortification since 1998, i.e. about twice more than supplemental intake initially predicted (Choumenkovitch et al. 2002). Thus, the prevalence of individuals with a folic acid intake above the upper tolerable intake level ( $1 \mathrm{mg}$ folic acid/d) increased from 1.3 to $11.3 \%$ in supplement consumers exposed to the fortification. Additionally, the supply of micronutrients by vitamin and mineral supplements may be highly variable and thereby be harmful. For instance, the long-term increased intake of vitamin A may promote the development of osteoporotic hip fractures in post-menopausal women (Feskanich et al. 2002).

Since the start of folic acid fortification, a steady increase in the indicators of plasma folate status has been observed in various groups of the American, Chilean and Canadian populations, including the elderly, who did not use vitamin supplements (Jacques et al. 1999b; Hirsch et al. 2002a). Folate intake via a multivitamin supplement formulated at about $100 \%$ daily value for most vitamins and minerals was found to be of further benefit among free-living older adults already consuming a diet fortified with folic acid in improving B-vitamin status and reducing tHcy (McKay et al. 2000). However, interest in increased folate intake on the risk of chronic diseases needs to be balanced against concerns on the general lack of data about safety of continuous high intakes (Meltzer et al. 2003). Although folic acid, as well as the other B vitamins except vitamin $\mathrm{B}_{6}$ and niacin, is generally considered as safe in therapeutic use, there are currently insufficient data from human or animal investigations to define a safety upper limit for B vitamins (Expert Group on Vitamins and Minerals, 2003). Recently, it has been reported that longterm high folic acid supplementation may reduce $\mathrm{N}$ digestive function in aged rats (Achon et al. 2002). Additionally, it is worth considering that folate supplementation and fortification may potentiate the growth and progression of colon lesions, in the context of advanced colorectal tumorigenesis (Lamprecht \& Lipkin, 2003) and, more generally, diminish the effectiveness of drugs frequently used by the elderly. Moreover, the Canadian folic acid food fortification has not been concurrent with a significant decline in the prevalence of vitamin $\mathrm{B}_{12}$ insufficiency (Ray et al. 2002). It has been suggested that an increase in folate status could precipitate or worsen neurological dysfunction in vitamin $\mathrm{B}_{12}$-deficient individuals. Macrocytic anaemia, one of the first detectable clinical signs of vitamin $\mathrm{B}_{12}$ deficiency, can resolve following folic acid supplementation, so that neurological problems are the first signs to develop (Quinlivan et al. 2002). Concurrent supplementation or fortification with vitamin $\mathrm{B}_{12}$, especially in the elderly, might reduce concerns about adverse side effects from the consumption of high levels of folic acid and be also effective at the lowering of tHcy (Flood et al. 2001). However, the exact dose at which this occurs remains currently unknown, in part due to the difficulty of assessing vitamin $\mathrm{B}_{12}$ deficiency. Moreover, whereas oral administration of crystalline cyanocobalamin seems to be an effective treatment for food-cobalamin malabsorption, it remains unknown whether it is the same regarding vitamin $\mathrm{B}_{12}$ from fortified food (Russell et al. 2001).

The question as to whether elderly individuals have specific needs for certain B vitamins cannot be answered easily. Data on women aged 60-85 years (Kauwell et al. 2000) suggest the need to recommend a higher daily intake of folate for that group of the population, as compared with younger women usually taken as references for defining recommended dietary allowances. However, owing to difficulties in performing repeated depletion-repletion studies 
in older adults, data on specific recommendations are scarce for this age group. Moreover, recommended intakes of several B vitamins are usually expressed relative to energy intake, which is lower in older than in younger individuals. Despite some quantitative differences, the recommendations established in different countries generally agree on the specific requirements of $\mathrm{B}$ vitamins for the elderly population. Based on the use of biochemical indicator cut-off values, the daily requirements of B vitamins for elderly individuals have been judged either similar to (vitamins $\mathrm{B}_{1}, \mathrm{~B}_{2}$, folate, vitamin $\mathrm{B}_{12}$ ) or higher than (vitamin $B_{6}$ ) those for young adults (for instance, see Institute of Medicine, National Academy of Sciences, 1998; AFSSA \& CNERNA-CNRS, 2001). However, the use of supplements of vitamin $\mathrm{B}_{12}$ or vitamin $\mathrm{B}_{12}$-fortified food products has been advised for individuals aged over 50 years by the US Institute of Medicine, National Academy of Sciences (1998).

Indices of wellbeing were improved in elderly women with marginal thiamin deficiency following supplementation with high doses of thiamin (Smidt et al. 1991). Vitamin $\mathrm{B}_{6}$, cobalamin and/or folic acid treatment, as well as the intake of multivitamin mix, increased serum vitamin levels while lowering serum MMA and tHcy levels in the elderly (Tucker et al. 2000; Björkegren \& Svärdsudd, 2001; McKinley et al. 2001). In healthy elderly subjects with erythrocyte glutathione reductase activity coefficient and plasma PLP values indicative of insufficient vitamin $B_{2}$ and $\mathrm{B}_{6}$ status, respectively, supplementation with physiological doses of riboflavin also improved both biochemical markers (Madigan et al. 1998). These results confirmed the biochemical interdependency of these two vitamins, but also suggested that only riboflavin was limiting. However, in a similar study, riboflavin, unlike folic acid, did not appear to be an effective tHcy-lowering agent despite the metabolic dependency of thcy on vitamin $\mathrm{B}_{2}$ (McKinley et al. 2002). In individuals with baseline concentrations of $12 \mu \mathrm{M}$ and $12 \mathrm{nM}$ for Hcy and folate, respectively, there appears to be a tHcy-lowering effect plateauing with supplemental doses of folic acid of 400-500 $\mu \mathrm{g} / \mathrm{d}$ (Bailey et al. 2003). However, nutrient-dense foods containing physiological amounts of various micronutrients decreased tHcy and MMA concentrations in free-living Dutch frail elderly individuals during a 17-week randomised controlled intervention trial (de Jong et al. 2001). Currently, the amount of folate required to enhance body stores to levels that would be protective against chronic diseases is unclear and, consequently, it remains unknown whether natural foods can or cannot deliver such an amount. The ongoing large-scale randomised controlled intervention trials (for example, NORVIT, VITATOPS, SEARCH, VITAL, SU.FOL.OM3) that are underway in several countries should shed light on the effect of folic acid and other B vitamin supplementation on chronic disease occurrence. However, these secondary intervention trials in patients will bring limited information, if any, on the actual protective effects of B vitamins against chronic diseases in healthy adults. So far, a change in the food practices of individuals toward a balanced diet, rich in varied fruit and vegetables, remains much preferable to the intake of enriched foodstuffs or to the intake of additional multivitamin mix (Bernstein et al. 2002).

\section{Conclusions}

There is currently good epidemiological evidence that the elderly population is at risk of insufficient status of several $\mathrm{B}$ vitamins. This has been associated with an increased risk of degenerative diseases including vascular diseases, cognitive and neurological dysfunction and cancers. However, there are differences between the data currently available due to many factors. These include the diversity of followup duration, the population sample size and ethnic origin. Other factors are the health and B vitamin status of the enrolled subjects and the parameters used to evaluate their dysfunctioning, the possible adjustment for covariates, the availability of baseline data, accuracy of metabolic markers and cut-off values used for determining B vitamin status, and the precision of estimates of micronutrient intake through dietary questionnaires and current food composition tables. Further longitudinal prospective studies before there are signs of health alteration are particularly needed to demonstrate that subtle B vitamin deficiency or concurrent alteration of biochemical indices (for example, homocysteinaemia) is causal to the aetiology of each of these pathologies.

Moreover, there is still progress to be made as regards in vivo assessments of the bioavailability of naturally occurring $\mathrm{B}$ vitamins in human subjects, with consideration for current food processing and cooking conditions (Wright et al. 2003). Also, possible alterations in the mechanisms of folate bioavailability in elderly individuals, on the one hand, and consequences of folate deficiency, on the other, deserve investigation at the molecular level using animal and cell-culture models. The metabolic fate and cellular effects of high doses of folic acid will shed light on the assumed risk of folic acid fortification and/or supplementation with vitamin and mineral mixtures. Regarding vitamin $\mathrm{B}_{6}$, studies are needed to determine the mechanisms underlying the apparently increased requirement of elderly individuals for this vitamin. Finally, future research projects should consider $B$ vitamins, other than folate, vitamins $B_{6}$, $B_{12}$ and $B_{2}$, which have yet been little studied because of the current poor understanding of their public health significance.

Overall, data from future studies should allow us to better define whether proper nutrition, i.e. as micronutrient-dense food, starting at a younger age, has a protective effect against degenerative diseases and whether elderly individuals deserve particular attention regarding their B vitamin status.

\section{References}

Achon M, Alonso-Aperts E \& Varela-Moreiras G (2002) High dietary folate supplementation: effects on diet utilization and methionine metabolism in aged rats. Journal of Nutrition, Health and Aging 6, 51-54.

AFSSA \& CNERNA-CNRS (2001) Apports Nutritionnels Conseillés pour la Population Française, 3rd ed. Paris: Technique \& Documentation.

Amorim Cruz JA, Moreiras O \& Brzozowska A (1996) Longitudinal changes in the intake of vitamins and minerals of elderly Europeans. SENECA Investigators. European Journal of Clinical Nutrition 50, Suppl. 2, S77-S85.

Baik HW \& Russell RM (1999) Vitamin B12 deficiency in the elderly. Annual Review of Nutrition 19, 357-377. 
Bailey LB, Cerda JJ, Bloch BS, Busby MJ, Vargas L, Chandler CJ \& Halsted CH (1984) Effect of age on poly- and monoglutamyl folacin absorption in human subjects. Journal of Nutrition 114, 1770-1776.

Bailey AL, Maisey S, Southon S, Wright AJ, Finglas PM \& Fulcher RA (1997) Relationships between micronutrient intake and biochemical indicators of nutrient adequacy in a 'free-living' elderly UK population. British Journal of Nutrition 77, 225-242.

Bailey LB, Rampersaud GC \& Kauwell GP (2003) Folic acid supplements and fortification affect the risk for neural tube defects, vascular disease and cancer: evolving science. Journal of Nutrition 133, 1961S-1968S.

Benderitter M, Hadj-Saad F, Lhuissier M, Maupoil V, Guilland JC \& Rochette L (1996) Effects of exhaustive exercise and vitamin B6 deficiency on free radical oxidative process in male trained rats. Free Radical Biology and Medicine 21, 541-549.

Bernstein MA, Tucker KL, Ryan ND, O’Neill EF, Clements KM, Nelson ME, Evans WJ \& Fiatarone Singh MA (2002) Higher dietary variety is associated with better nutritional status in frail elderly people. Journal of the American Dietetic Association 102, 1096-1104.

Bird CL, Swendseid ME, Witte JS, Shikany JM, Hunt IF, Frankl HD, Lee ER, Longnecker MP \& Haile RW (1995) Red cell and plasma folate, folate consumption, and the risk of colorectal adenomatous polyps. Cancer Epidemiology, Biomarkers and Prevention 4, 709-714.

Björkegren K \& Svärdsudd K (2001) Serum cobalamin, folate, methylmalonic acid and total homocysteine as vitamin B12 and folate tissue deficiency markers amongst elderly Swedes - a population-based study. Journal of Internal Medicine 249, 423-432.

Boisvert WA, Castaneda C, Mendoza I, Langeloh G, Solomons NW, Gershoff SN \& Russell RM (1993) Prevalence of riboflavin deficiency among Guatemalan elderly people and its relationship to milk intake. American Journal of Clinical Nutrition 58, 85-90.

Boushey CJ, Beresford SA, Omenn GS \& Motulsky AG (1995) A quantitative assessment of plasma homocysteine as a risk factor for vascular disease. Probable benefits of increasing folic acid intakes. Journal of the American Medical Association 274, 1049-1057.

Broekmans WM, Klopping-Ketelaars IA, Schuurman CR, Verhagen H, van den Berg H, Kok FJ \& van Poppel G (2000) Fruits and vegetables increase plasma carotenoids and vitamins and decrease homocysteine in humans. Journal of Nutrition 130, 1578-1583.

Brouwer IA, van Dusseldorp M, West CE, Meyboom S, Thomas CM, Duran M, van het Hof KH, Eskes TK, Hautvast JG \& Steegers-Theunissen RP (1999) Dietary folate from vegetables and citrus fruit decreases plasma homocysteine concentrations in humans in a dietary controlled trial. Journal of Nutrition 129, $1135-1139$.

Brouwer IA, van Dusseldorp M, West CE \& Steegers-Theunissen RPM (2001) Bioavailability and bioefficacy of folate and folic acid in man. Nutrition Research Reviews 14, 267-293.

Camilo E, Zimmerman J, Mason JB, Golner B, Russell R, Selhub J \& Rosenberg IH (1996) Folate synthesized by bacteria in the human upper small intestine is assimilated by the host. Gastroenterology 110, 991-998.

Chasan-Taber L, Selhub J, Rosenberg IH, Malinow MR, Terry P, Tishler PV, Willett W, Hennekens CH \& Stampfer MJ (1996) A prospective study of folate and vitamin B6 and risk of myocardial infarction in US physicians. Journal of the American College of Nutrition 15, 136-143.

Choi SW \& Mason JB (2002) Folate status: effects on pathways of colorectal carcinogenesis. Journal of Nutrition 132, 2413S2418 S.
Choumenkovitch SF, Selhub J, Wilson PW, Rader JI, Rosenberg IH \& Jacques PF (2002) Folic acid intake from fortification in United States exceeds predictions. Journal of Nutrition 132 , 2792-2798.

Clarke R, Refsum H, Birks J, Evans JG, Johnston C, Sherliker P, Ueland PM, Schneede J, McPartlin J, Nexo E \& Scott JM (2003) Screening for vitamin B-12 and folate deficiency in older individuals. American Journal of Clinical Nutrition $\mathbf{7 7}$, 1241-1247.

de Bree A, Verschuren WM, Bjorke-Monsen AL, van der Put NM, Heil SG, Trijbels FJ \& Blom HJ (2003) Effect of the methylenetetrahydrofolate reductase $677 \mathrm{C} \rightarrow>$ T mutation on the relations among folate intake and plasma folate and homocysteine concentrations in a general population sample. American Journal of Clinical Nutrition 77, 687-693.

de Jong N, Paw MJ, de Groot LC, Rutten RA, Swinkels DW, Kok FJ \& van Staveren WA (2001) Nutrient-dense foods and exercise in frail elderly: effects on B vitamins, homocysteine, methylmalonic acid, and neuropsychological functioning. American Journal of Clinical Nutrition 73, 338-346.

Desouza C, Keebler M, McNamara DB \& Fonseca V (2002) Drugs affecting homocysteine metabolism: impact on cardiovascular risk. Drugs 62, 605-616.

Doshi SN, McDowell IF, Moat SJ, Payne N, Durrant HJ, Lewis MJ \& Goodfellow J (2002) Folic acid improves endothelial function in coronary artery disease via mechanisms largely independent of homocysteine lowering. Circulation 105, 22-26.

Duan W, Ladenheim B, Cutler RG, Kruman, II, Cadet JL \& Mattson MP (2002) Dietary folate deficiency and elevated homocysteine levels endanger dopaminergic neurons in models of Parkinson's disease. Journal of Neurochemistry 80, 101-110.

Duell PB \& Malinow MR (1997) Homocyst(e)ine: an important risk factor for atherosclerotic vascular disease. Current Opinion in Lipidology 8, 28-34.

Duthie SJ, Narayanan S, Brand GM, Pirie L \& Grant G (2002) Impact of folate deficiency on DNA stability. Journal of Nutrition 132, 2444S-2449S.

Ervin RB, Wright JD \& Kennedy-Stephenson J (1999) Use of dietary supplements in the United States, 1988-94. Vital and Health Statistics. Series 11, i-iii, 1-14.

Essama-Tjani JC, Guilland JC, Potier de Courcy G, Fuchs F \& Richard D (2000) Folate status worsens in recently institutionalized elderly people without evidence of functional deterioration. Journal of the American College of Nutrition 19, 392-404.

Eussen SJ, Ferry M, Hininger I, Haller J, Matthys C \& Dirren H (2002) Five year changes in mental health and associations with vitamin B12/folate status of elderly Europeans. Journal of Nutrition, Health and Aging 6, 43-50.

Expert Group on Vitamins and Minerals (2003) Safe upper levels for vitamins and minerals: report. www.foodstandards.gov.uk/ science/ouradvisors/vitandmin/

Fenech M (2002) Micronutrients and genomic stability: a new paradigm for recommended dietary allowances (RDAs). Food and Chemical Toxicology 40, 1113-1117.

Feskanich D, Singh V, Willett WC \& Colditz GA (2002) Vitamin A intake and hip fractures among postmenopausal women. Journal of the American Medical Association 287, 47-54.

Finkelstein JD (1998) The metabolism of homocysteine: pathways and regulation. European Journal of Pediatrics 157, Suppl. 2, S40-S44.

Flood VM, Webb KL, Smith W, Mitchell P, Bantick JM, Macintyre R, Sindhusake D \& Rubin GL (2001) Folate fortification: potential impact on folate intake in an older population. European Journal of Clinical Nutrition 55, 793-800.

Folsom AR, Nieto FJ, McGovern PG, Tsai MY, Malinow MR, Eckfeldt JH, Hess DL \& Davis CE (1998) Prospective study of coronary heart disease incidence in relation to fasting total 
homocysteine, related genetic polymorphisms, and B vitamins: the Atherosclerosis Risk in Communities (ARIC) study. Circulation 98, 204-210.

Fuchs CS, Willett WC, Colditz GA, Hunter DJ, Stampfer MJ, Speizer FE \& Giovannucci EL (2002) The influence of folate and multivitamin use on the familial risk of colon cancer in women. Cancer Epidemiology, Biomarkers and Prevention 11, 227-234.

Gastaldi G, Laforenza U, Ferrari G, Casasco A \& Rindi G (1992) Age-related thiamin transport by small intestinal microvillous vesicles of rat. Biochimica Biophysica Acta 1105, 271-277.

Ghandour H, Lin BF, Choi SW, Mason JB \& Selhub J (2002) Folate status and age affect the accumulation of L-isoaspartyl residues in rat liver proteins. Journal of Nutrition 132, 1357-1360.

Giles WH, Kittner SJ, Croft JB, Anda RF, Casper ML \& Ford ES (1998) Serum folate and risk for coronary heart disease: results from a cohort of US adults. Annals of Epidemiology 8, 490-496.

Giovannucci E (2002) Epidemiologic studies of folate and colorectal neoplasia: a review. Journal of Nutrition 132, 2350S-2355S.

Gold M, Chen MF \& Johnson K (1995) Plasma and red blood cell thiamine deficiency in patients with dementia of the Alzheimer's type. Archives of Neurology 52, 1081-1086.

Gonzalez-Gross M, Marcos A \& Pietrzik K (2001) Nutrition and cognitive impairment in the elderly. British Journal of Nutrition 86, 313-321.

Gregory JF III (1998) Nutritional properties and significance of vitamin glycosides. Annual Review of Nutrition 18, 277-296.

Gregory JF III \& Quinlivan EP (2002) In vivo kinetics of folate metabolism. Annual Review of Nutrition 22, 199-220.

Haller J (1999) The vitamin status and its adequacy in the elderly: an international overview. International Journal for Vitamin and Nutrition Research 69, 160-168.

Hartman TJ, Woodson K, Stolzenberg-Solomon R, Virtamo J, Selhub J, Barrett MJ \& Albanes D (2001) Association of the Bvitamins pyridoxal 5'-phosphate $(\mathrm{B}(6)), \mathrm{B}(12)$, and folate with lung cancer risk in older men. American Journal of Epidemiology 153, 688-694.

Heijmans BT, Boer JM, Suchiman HE, Cornelisse CJ, Westendorp RG, Kromhout D, Feskens EJ \& Slagboom PE (2003) A common variant of the methylenetetrahydrofolate reductase gene (1p36) is associated with an increased risk of cancer. Cancer Research 63, 1249-1253.

Herrmann W, Quast S, Ullrich M, Schultze H, Bodis M \& Geisel J (1999) Hyperhomocysteinemia in high-aged subjects: relation of B-vitamins, folic acid, renal function and the methylenetetrahydrofolate reductase mutation. Atherosclerosis 144, 91-101.

Hirsch S, de la Maza P, Barrera G, Gattas V, Petermann M \& Bunout D (2002a) The Chilean flour folic acid fortification program reduces serum homocysteine levels and masks vitamin B-12 deficiency in elderly people. Journal of Nutrition 132, 289-291.

Hirsch S, de la Maza P, Mendoza L, Petermann M, Glasinovic A, Paulinelli P, Barrera G, Rosenberg IH \& Bunout D (2002b) Endothelial function in healthy younger and older hyperhomocysteinemic subjects. Journal of the American Geriatrics Society 50, 1019-1023.

Homocysteine Lowering Trialists' Collaboration (1998) Lowering blood homocysteine with folic acid based supplements: metaanalysis of randomised trials. British Medical Journal 316, 894-898.

Howard JM, Azen C, Jacobsen DW, Green R \& Carmel R (1998) Dietary intake of cobalamin in elderly people who have abnormal serum cobalamin, methylmalonic acid and homocysteine levels. European Journal of Clinical Nutrition 52, 582-587.

Huang RF, Hsu YC, Lin HL \& Yang FL (2001) Folate depletion and elevated plasma homocysteine promote oxidative stress in rat livers. Journal of Nutrition 131, 33-38.
Institute of Medicine, National Academy of Sciences (1998) Dietary Reference Intakes for Thiamin, Riboflavin, Niacin, Vitamin B6, Folate, Vitamin B12, Pantothenic Acid, Biotin and Choline. Washington, DC: National Academy Press. www.iom.edu/

Jacques PF, Bostom AG, Wilson PW, Rich S, Rosenberg IH \& Selhub J (2001) Determinants of plasma total homocysteine concentration in the Framingham offspring cohort. American Journal of Clinical Nutrition 73, 613-621.

Jacques PF, Rosenberg IH, Rogers G, Selhub J, Bowman BA, Gunter EW, Wright JD \& Johnson CL (1999a) Serum total homocysteine concentrations in adolescent and adult Americans: results from the third National Health and Nutrition Examination Survey. American Journal of Clinical Nutrition 69, 482-489.

Jacques PF, Selhub J, Bostom AG, Wilson PW \& Rosenberg IH (1999b) The effect of folic acid fortification on plasma folate and total homocysteine concentrations. New England Journal of Medicine 340, 1449-1454.

James SJ, Melnyk S, Pogribna M, Pogribny IP \& Caudill MA (2002) Elevation in S-adenosylhomocysteine and DNA hypomethylation: potential epigenetic mechanism for homocysteine-related pathology. Journal of Nutrition 132, 2361S2366S.

Jatoi A, Daly BD, Kramer G \& Mason JB (2001) Folate status among patients with non-small cell lung cancer: a case-control study. Journal of Surgery and Oncology 77, 247-252.

Jimenez-Jimenez FJ, Molina JA, Hernanz A, Fernandez-Vivancos E, de Bustos F, Barcenilla B, Gomez-Escalonilla C, Zurdo M, Berbel A \& Villanueva C (1999) Cerebrospinal fluid levels of thiamine in patients with Parkinson's disease. Neuroscience Letters 271, 33-36.

Joshi R, Adhikari S, Patro BS, Chattopadhyay S \& Mukherjee T (2001) Free radical scavenging behavior of folic acid: evidence for possible antioxidant activity. Free Radical Biology and Medicine 30, 1390-1399.

Kalmijn S, Launer LJ, Lindemans J, Bots ML, Hofman A \& Breteler MM (1999) Total homocysteine and cognitive decline in a community-based sample of elderly subjects: the Rotterdam Study. American Journal of Epidemiology 150, 283-289.

Kauwell GP, Lippert BL, Wilsky CE, Herrlinger-Garcia K, Hutson AD, Theriaque DW, Rampersaud GC, Cerda JJ \& Bailey LB (2000) Folate status of elderly women following moderate folate depletion responds only to a higher folate intake. Journal of Nutrition 130, 1584-1590.

Kesavan V \& Noronha JM (1983) Folate malabsorption in aged rats related to low levels of pancreatic folyl conjugase. American Journal of Clinical Nutrition 37, 262-267.

Khosraviani K, Weir HP, Hamilton P, Moorehead J \& Williamson K (2002) Effect of folate supplementation on mucosal cell proliferation in high risk patients for colon cancer. Gut 51, 195-199.

Klerk M, Verhoef P, Clarke R, Blom HJ, Kok FJ \& Schouten EG (2002) MTHFR 677C $-\rightarrow$ T polymorphism and risk of coronary heart disease: a meta-analysis. Jama 288, 2023-2031.

Konings EJ, Goldbohm RA, Brants HA, Saris WH \& Van Den Brandt PA (2002) Intake of dietary folate vitamers and risk of colorectal carcinoma. Cancer 95, 1421-1433.

Lamprecht SA \& Lipkin M (2003) Chemoprevention of colon cancer by calcium, vitamin D and folate: molecular mechanisms. Nature Reviews. Cancer 3, 601-614.

Lang D, Kredan MB, Moat SJ, Hussain SA, Powell CA, Bellamy MF, Powers HJ \& Lewis MJ (2000) Homocysteine-induced inhibition of endothelium-dependent relaxation in rabbit aorta: role for superoxide anions. Arteriosclerosis, Thrombosis and Vascular Biology 20, 422-427. 
Le Marchand L, Donlon T, Hankin JH, Kolonel LN, Wilkens LR \& Seifried A (2002) B-vitamin intake, metabolic genes, and colorectal cancer risk (United States). Cancer Causes and Control 13, 239-248.

Lievers KJ, Kluijtmans LA \& Blom HJ (2003) Genetics of hyperhomocysteinaemia in cardiovascular disease. Annals of Clinical Biochemistry 40, 46-59.

Lindeman RD, Romero LJ, Koehler KM, Liang HC, LaRue A, Baumgartner RN \& Garry PJ (2000) Serum vitamin B12, C and folate concentrations in the New Mexico elder health survey: correlations with cognitive and affective functions. Journal of the American College of Nutrition 19, 68-76.

Lopez-Sobaler AM, Ortega RM, Quintas ME, Navarro AR, Aparicio A, Gomez-Rodriguez N, Cocho M \& Requejo AM (2002) The influence of vitamin B2 intake on the activation coefficient of erythrocyte glutation reductase in the elderly. Journal of Nutrition, Health and Aging 6, 60-62.

Ma J, Stampfer MJ, Giovannucci E, Artigas C, Hunter DJ, Fuchs C, Willett WC, Selhub J, Hennekens CH \& Rozen R (1997) Methylenetetrahydrofolate reductase polymorphism, dietary interactions, and risk of colorectal cancer. Cancer Research 57, 1098-1102.

McKay DL, Perrone G, Rasmussen H, Dallal G \& Blumberg JB (2000) Multivitamin/mineral supplementation improves plasma B-vitamin status and homocysteine concentration in healthy older adults consuming a folate-fortified diet. Journal of Nutrition 130, 3090-3096.

McKinley MC, McNulty H, McPartlin J, Strain JJ, Pentieva K, Ward M, Weir DG \& Scott JM (2001) Low-dose vitamin B-6 effectively lowers fasting plasma homocysteine in healthy elderly persons who are folate and riboflavin replete. American Journal of Clinical Nutrition 73, 759-764.

McKinley MC, McNulty H, McPartlin J, Strain JJ \& Scott JM (2002) Effect of riboflavin supplementation on plasma homocysteine in elderly people with low riboflavin status. European Journal of Clinical Nutrition 56, 850-856.

McNulty H, McKinley MC, Wilson B, McPartlin J, Strain JJ, Weir DG \& Scott JM (2002) Impaired functioning of thermolabile methylenetetrahydrofolate reductase is dependent on riboflavin status: implications for riboflavin requirements. American Journal of Clinical Nutrition 76, 436-441.

Madigan SM, Tracey F, McNulty H, Eaton-Evans J, Coulter J, McCartney H \& Strain JJ (1998) Riboflavin and vitamin B-6 intakes and status and biochemical response to riboflavin supplementation in free-living elderly people. American Journal of Clinical Nutrition 68, 389-395.

Malinow MR, Duell PB, Hess DL, Anderson PH, Kruger WD, Phillipson BE, Gluckman RA, Block PC \& Upson BM (1998) Reduction of plasma homocyst(e)ine levels by breakfast cereal fortified with folic acid in patients with coronary heart disease. New England Journal of Medicine 338, 1009-1015.

Marshall TA, Stumbo PJ, Warren JJ \& Xie XJ (2001) Inadequate nutrient intakes are common and are associated with low diet variety in rural, community-dwelling elderly. Journal of Nutrition 131, 2192-2196.

Mason JB (2003) Biomarkers of nutrient exposure and status in one-carbon (methyl) metabolism. Journal of Nutrition 133, Suppl. 3, 941S-947S.

Mattson MP, Kruman II \& Duan W (2002) Folic acid and homocysteine in age-related disease. Ageing Research Reviews 1, 95-111.

Maxwell CJ, Hogan DB \& Ebly EM (2002) Serum folate levels and subsequent adverse cerebrovascular outcomes in elderly persons. Dementia and Geriatric Cognitive Disorders 13, 225-234.

Medrano MJ, Sierra MJ, Almazan J, Olalla MT \& Lopez-Abente G (2000) The association of dietary folate, B6, and B12 with cardiovascular mortality in Spain: an ecological analysis. American Journal of Public Health 90, 1636-1638.
Meleady R, Ueland PM, Blom H, Whitehead AS, Refsum H, Daly LE, Vollset SE, Donohue C, Giesendorf B, Graham IM, Ulvik A, Zhang Y \& Bjorke Monsen AL (2003) Thermolabile methylenetetrahydrofolate reductase, homocysteine, and cardiovascular disease risk: the European Concerted Action Project. American Journal of Clinical Nutrition 77, 63-70.

Meltzer HM, Aro A, Andersen NL, Koch B \& Alexander J (2003) Risk analysis applied to food fortification. Public Health Nutrition 6, 281-291.

Miller JW, Green R, Mungas DM, Reed BR \& Jagust WJ (2002) Homocysteine, vitamin B6, and vascular disease in $\mathrm{AD}$ patients. Neurology 58, 1471-1475.

Miller JW, Green R, Ramos MI, Allen LH, Mungas DM, Jagust WJ \& Haan MN (2003) Homocysteine and cognitive function in the Sacramento Area Latino Study on Aging. American Journal of Clinical Nutrition 78, 441-447.

Moat SJ, Bonham JR, Cragg RA \& Powers HJ (2000) Elevated plasma homocysteine elicits an increase in antioxidant enzyme activity. Free Radical Research 32, 171-179.

Moat SJ, Hill MH, McDowell IF, Pullin CH, Ashfield-Watt PA, Clark ZE, Whiting JM, Newcombe RG, Lewis MJ \& Powers HJ (2003) Reduction in plasma total homocysteine through increasing folate intake in healthy individuals is not associated with changes in measures of antioxidant activity or oxidant damage. European Journal of Clinical Nutrition 57, 483-489.

Nichols HK \& Basu TK (1994) Thiamin status of the elderly: dietary intake and thiamin pyrophosphate response. Journal of the American College of Nutrition 13, 57-61.

Niculescu MD \& Zeisel SH (2002) Diet, methyl donors and DNA methylation: interactions between dietary folate, methionine and choline. Journal of Nutrition 132, 2333S-2335S.

Nightingale AK, James PP, Morris-Thurgood J, Harrold F, Tong R, Jackson SK, Cockcroft JR \& Frenneaux MP (2001) Evidence against oxidative stress as mechanism of endothelial dysfunction in methionine loading model. American Journal of Physiology 280, H1334-H1339.

Nygard O, Vollset SE, Refsum H, Stensvold I, Tverdal A, Nordrehaug JE, Ueland M \& Kvale G (1995) Total plasma homocysteine and cardiovascular risk profile. The Hordaland Homocysteine Study. Journal of the American Medical Association 274, 1526-1533.

Olivares M, Hertrampf E, Capurro MT \& Wegner D (2000) Prevalence of anemia in elderly subjects living at home: role of micronutrient deficiency and inflammation. European Journal of Clinical Nutrition 54, 834-839.

Olszewski AJ \& McCully KS (1993) Homocysteine metabolism and the oxidative modification of proteins and lipids. Free Radical Biololgy and Medicine 14, 683-693.

Platz EA, Giovannucci E, Rimm EB, Rockett HR, Stampfer MJ, Colditz GA \& Willett WC (1997) Dietary fiber and distal colorectal adenoma in men. Cancer Epidemiology, Biomarkers and Prevention 6, 661-670.

Potter JD (2002) Methyl supply, methyl metabolizing enzymes and colorectal neoplasia. Journal of Nutrition 132, 2410S2412S.

Quinlivan EP, McPartlin J, McNulty H, Ward M, Strain JJ, Weir DG \& Scott JM (2002) Importance of both folic acid and vitamin B12 in reduction of risk of vascular disease. Lancet $\mathbf{3 5 9}$, 227-228.

Quinn K \& Basu TK (1996) Folate and vitamin B12 status of the elderly. European Journal of Clinical Nutrition 50, 340-342.

Raghuveer G, Sinkey CA, Chenard C, Stumbo P \& Haynes WG (2001) Effect of vitamin $E$ on resistance vessel endothelial dysfunction induced by methionine. American Journal of Cardiology 88, 285-290.

Rampersaud GC, Kauwell GP, Hutson AD, Cerda JJ \& Bailey LB (2000) Genomic DNA methylation decreases in response to 
moderate folate depletion in elderly women. American Journal of Clinical Nutrition 72, 998-1003.

Ravaglia G, Forti P, Maioli F, Bastagli L, Facchini A, Mariani E, Savarino L, Sassi S, Cucinotta D \& Lenaz G (2000) Effect of micronutrient status on natural killer cell immune function in healthy free-living subjects aged $>/=90$ y. American Journal of Clinical Nutrition 71, 590-598.

Ravaglia G, Forti P, Maioli F, Muscari A, Sacchetti L, Arnone G, Nativio V, Talerico T \& Mariani E (2003) Homocysteine and cognitive function in healthy elderly community dwellers in Italy. American Journal of Clinical Nutrition 77, 668-673.

Ray JG, Vermeulen MJ, Boss SC \& Cole DE (2002) Declining rate of folate insufficiency among adults following increased folic acid food fortification in Canada. Canadian Journal of Public Health 93, 249-253.

Robinson K, Arheart K, Refsum H, Brattstrom L, Boers G, Ueland P, Rubba P, Palma-Reis R, Meleady R, Daly L, Witteman J \& Graham I (1998) Low circulating folate and vitamin B6 concentrations: risk factors for stroke, peripheral vascular disease, and coronary artery disease. European COMAC group. Circulation 97, 437-443.

Rooprai HK, Pratt OE, Shaw GK \& Thomson AD (1990) The age dependence of the activity and activation of human red blood cell transketolase. Alcohol and Alcoholism 25, 453-456.

Rucker RB (editor) (2001) Handbook of Vitamins, 3rd ed. New York and Basel: Marcel Dekker, Inc.

Russell RM (2000) The aging process as a modifier of metabolism. American Journal of Clinical Nutrition 72, 529S-532S.

Russell RM, Baik H \& Kehayias JJ (2001) Older men and women efficiently absorb vitamin B-12 from milk and fortified bread. Journal of Nutrition 131, 291-293.

Savage DG, Lindenbaum J, Stabler SP \& Allen RH (1994) Sensitivity of serum methylmalonic acid and total homocysteine determinations for diagnosing cobalamin and folate deficiencies. American Journal of Medicine 96, 239-246.

Saw SM, Yuan JM, Ong CN, Arakawa K, Lee HP, Coetzee GA \& Yu MC (2001) Genetic, dietary, and other lifestyle determinants of plasma homocysteine concentrations in middle-aged and older Chinese men and women in Singapore. American Journal of Clinical Nutrition 73, 232-239.

Seekamp A, Hultquist DE \& Till GO (1999) Protection by vitamin B2 against oxidant-mediated acute lung injury. Inflammation 23, 449-460.

Selhub J, Jacques PF, Wilson PW, Rush D \& Rosenberg IH (1993) Vitamin status and intake as primary determinants of homocysteinemia in an elderly population. Journal of the American Medical Association 270, 2693-2698.

Selley ML, Close DR \& Stern SE (2002) The effect of increased concentrations of homocysteine on the concentration of (E)-4hydroxy-2-nonenal in the plasma and cerebrospinal fluid of patients with Alzheimer's disease. Neurobiology of Aging 23, 383-388.

Seshadri S, Beiser A, Selhub J, Jacques PF, Rosenberg IH, D'Agostino RB, Wilson PW \& Wolf PA (2002) Plasma homocysteine as a risk factor for dementia and Alzheimer's disease. New England Journal of Medicine 346, 476-483.

Shannon B, Gnanasampanthan S, Beilby J \& Iacopetta B (2002) A polymorphism in the methylenetetrahydrofolate reductase gene predisposes to colorectal cancers with microsatellite instability. Gut 50, 520-524.

Shimizu H, Kiyohara Y, Kato I, Tanizaki Y, Ueno H, Kimura Y, Iwamoto H, Kubo M, Arima H, Ibayashi S \& Fujishima M (2002) Plasma homocyst(e)ine concentrations and the risk of subtypes of cerebral infarction. The Hisayama study. Cerebrovascular Diseases 13,9-15.

Smidt LJ, Cremin FM, Grivetti LE \& Clifford AJ (1991) Influence of thiamin supplementation on the health and general well- being of an elderly Irish population with marginal thiamin deficiency. Journal of Gerontology 46, M16-M22.

Stern LL, Mason JB, Selhub J \& Choi SW (2000) Genomic DNA hypomethylation, a characteristic of most cancers, is present in peripheral leukocytes of individuals who are homozygous for the C677T polymorphism in the methylenetetrahydrofolate reductase gene. Cancer Epidemiology, Biomarkers and Prevention 9, 849-853.

Stolzenberg-Solomon RZ, Albanes D, Nieto FJ, Hartman TJ, Tangrea JA, Rautalahti M, Sehlub J, Virtamo J \& Taylor PR (1999) Pancreatic cancer risk and nutrition-related methylgroup availability indicators in male smokers. Journal of the National Cancer Institute 91, 535-541.

Su LJ \& Arab L (2001) Nutritional status of folate and colon cancer risk: evidence from NHANES I epidemiologic follow-up study. Annals of Epidemiology 11, 65-72.

Sydow K, Schwedhelm E, Arakawa N, Bode-Boger SM, Tsikas D, Hornig B, Frolich JC \& Boger RH (2003) ADMA and oxidative stress are responsible for endothelial dysfunction in hyperhomocyst(e)inemia: effects of L-arginine and $\mathrm{B}$ vitamins. Cardiovascular Research 57, 244-252.

Symons JD, Mullick AE, Ensunsa JL, Ma AA \& Rutledge JC (2002) Hyperhomocysteinemia evoked by folate depletion: effects on coronary and carotid arterial function. Arteriosclerosis, Thrombosis and Vascular Biology 22, 772-780.

Teunissen CE, Blom AH, Van Boxtel MP, Bosma H, de Bruijn C, Jolles J, Wauters BA, Steinbusch HW \& de Vente J (2003) Homocysteine: a marker for cognitive performance? A longitudinal follow-up study. Journal of Nutrition, Health and Aging 7, 153-159.

Tiemeier H, van Tuijl HR, Hofman A, Meijer J, Kiliaan AJ \& Breteler MM (2002) Vitamin B12, folate, and homocysteine in depression: the Rotterdam Study. American Journal of Psychiatry 159, 2099-2101.

Tucker KL, Rich S, Rosenberg I, Jacques P, Dallal G, Wilson PW \& Selhub J (2000) Plasma vitamin B-12 concentrations relate to intake source in the Framingham Offspring study. American Journal of Clinical Nutrition 71, 514-522.

van Asselt DZ, de Groot LC, van Staveren WA, Blom HJ, Wevers RA, Biemond I \& Hoefnagels WH (1998) Role of cobalamin intake and atrophic gastritis in mild cobalamin deficiency in older Dutch subjects. American Journal of Clinical Nutrition 68, 328-334.

van Asselt DZ, Pasman JW, van Lier HJ, Vingerhoets DM, Poels PJ, Kuin Y, Blom HJ \& Hoefnagels WH (2001) Cobalamin supplementation improves cognitive and cerebral function in older, cobalamin-deficient persons. Journal of Gerontology 56A, M775-M779.

van den Berg H (1999) Vitamin B6 status and requirements in older adults. British Journal of Nutrition 81, 175-176.

van den Berg H, van der Gaag M \& Hendriks H (2002) Influence of lifestyle on vitamin bioavailability. International Journal for Vitamin and Nutrition Research 72, 53-59.

van der Wielen RP, Lowik MR, Haller J, van den Berg H, Ferry M \& van Staveren WA (1996) Vitamin B-6 malnutrition among elderly Europeans: the SENECA study. Journal of Gerontology 51A, B417-B424.

Ventura P, Panini R, Verlato C, Scarpetta G \& Salvioli G (2001) Hyperhomocysteinemia and related factors in 600 hospitalized elderly subjects. Metabolism 50, 1466-1471.

Verhaar MC, Wever RM, Kastelein JJ, van Dam T, Koomans HA \& Rabelink TJ (1998) 5-methyltetrahydrofolate, the active form of folic acid, restores endothelial function in familial hypercholesterolemia. Circulation 97, 237-241.

Voorrips LE, Goldbohn RA, Brants HA, van Poppel GA, Sturmans F, Hermus RV \& van den Brandt PA (2000) A prospective cohort study on antioxidant and folate intake and 
male lung cancer risk. Cancer Epidemiology Biomarkers \& Prevention 9, 357-365.

Wald DS, Law M \& Morris JK (2002) Homocysteine and cardiovascular disease: evidence on causality from a meta-analysis. British Medical Journal 325, 1202.

Wilkinson TJ, Hanger HC, George PM \& Sainsbury R (2000) Is thiamine deficiency in elderly people related to age or co-morbidity? Age and Ageing 29, 111-116.

Woo KS, Chook P, Chan LL, Cheung AS, Fung WH, Qiao M, Lolin YI, Thomas GN, Sanderson JE, Metreweli C \& Celermajer DS (2002) Long-term improvement in homocysteine levels and arterial endothelial function after 1-year folic acid supplementation. American Journal of Medicine 112, 535-539.

Wright AJ, Finglas PM, Dainby JR, Hart DJ, Wolfe CA, Southon S \& Gregory JF (2003) Single oral doses of 13C forms of pteroylmonoglutamic acid and 5-formyltetrahydrofolic acid elicit differences in short-term kinetics of labelled and unlabelled folates in plasma: potential problems in interpretation of folate bioavailability studies. British Journal of Nutrition $\mathbf{9 0}$, 363-371.

Zhang SM, Willett WC, Selhub J, Hunter DJ, Giovannucci EL, Holmes MD, Colditz GA \& Hankinson SE (2003) Plasma folate, vitamin B6, vitamin B12, homocysteine, and risk of breast cancer. Journal of the National Cancer Institute $\mathbf{9 5}$, 373-380.

Zhang X, Li H, Jin H, Ebin Z, Brodsky S \& Goligorsky MS (2000) Effects of homocysteine on endothelial nitric oxide production. American Journal of Physiology 279, F671-F678.

Ziegler RG, Weinstein SJ \& Fears TR (2002) Nutritional and genetic inefficiencies in one-carbon metabolism and cervical cancer risk. Journal of Nutrition 132, 2345S-2349S. 